Research Article

\title{
Removal of Iron(II) Using Intercalated Ca/Al Layered Double Hydroxides with $\left[\alpha-\mathrm{SiW}_{12} \mathrm{O}_{40}\right]^{4-}$
}

\author{
Tarmizi Taher ${ }^{2}$, Mikha Meilinda Christina ${ }^{1}$, Muhammad Said ${ }^{1}$, Nurlisa Hidayati ${ }^{1}$, \\ F. Ferlinahayati ${ }^{1}$, Aldes Lesbani ${ }^{12^{*}}$ \\ 1Department of Chemistry, Faculty of Mathematic and Natural Sciences, Universitas Sriwijaya, \\ Jl. Palembang Prabumulih Km.32 Ogan Ilir 30662, Indonesia \\ ${ }_{2}^{2}$ Environmental Science Study, Graduate Program, Universitas Sriwijaya, \\ Jl. Padang Selasa Bukit Besar Palembang 30139, Indonesia
}

Received: 1st July 2018; Revised: $5^{\text {th }}$ November 2018; Accepted: $9^{\text {th }}$ November 2018; Available online: 30th April 2019; Published regularly: 1st August 2019

\begin{abstract}
$\mathrm{Ca} / \mathrm{Al}$ layered double hydroxide $(\mathrm{LDH})$ was successfully synthesized by co-precipitation method at $\mathrm{pH}$ 11 under room temperature condition then followed by calcination at $800{ }^{\circ} \mathrm{C}$. The synthesized $\mathrm{Ca} / \mathrm{Al}$ $\mathrm{LDH}$ was further intercalated with Keggin ion $\left[\mathrm{a}^{-} \mathrm{SiW}_{12} \mathrm{O}_{40}\right]^{4-}$ in order to prepare the intercalated form of $\mathrm{Ca} / \mathrm{Al} \mathrm{LDH}$. The synthesized materials were characterized by X-ray diffraction (XRD) and Fourier transform infrared (FT-IR) and used as an adsorbent for iron(II) removal from the aqueous medium. The adsorption performance was investigated by studying the kinetics and thermodynamic properties of the adsorption process. The results showed that pristine $\mathrm{Ca} / \mathrm{Al} \mathrm{LDH}$ exhibited diffraction peak at $2 \theta$ about $20^{\circ}$ which corresponds to the layer structure of the $\mathrm{LDH}$ material. For the intercalated $\mathrm{Ca} / \mathrm{Al}$ $\mathrm{LDH}$, the diffraction observed at $2 \theta$ around $30-40^{\circ}$ indicated that the $\left[\mathrm{a}-\mathrm{SiW}_{12} \mathrm{O}_{40}\right]^{4-}$ was successfully intercalated into the interlayer space of $\mathrm{Ca} / \mathrm{Al} \mathrm{LDH}$. Furthermore, the intercalated $\mathrm{Ca} / \mathrm{Al} \mathrm{LDH}$ showed higher adsorption capacity toward iron(II) than the pristine form of $\mathrm{Ca} / \mathrm{Al} \mathrm{LDH}$. Copyright (C) 2019 BCREC Group. All rights reserved
\end{abstract}

Keywords: Layered Double Hydroxides; Iron(II); Keggin Ion; Adsorption

How to Cite: Taher, T., Christina, M.M., Said, M., Hidayati, N, Ferlinahayati, F., Lesbani, A. (2019). Removal of Iron(II) Using Intercalated Ca/Al Layered Double Hydroxides with $\left[\alpha-\mathrm{SiW}_{12} \mathrm{O}_{40}\right]^{4-}$. Bulletin of Chemical Reaction Engineering \& Catalysis, 14 (2): 260-267 (doi:10.9767/bcrec.14.2.2880.260-267)

Permalink/DOI: https://doi.org/10.9767/bcrec.14.2.2880.260-267

\section{Introduction}

The heavy metals pollution has been recognized as tremendous environmental problem in the current decade due to their high toxicity to any living creatures including human being. Moreover, the presence of heavy metals in the environment is hardly degraded naturally with-

*Corresponding Author.

Email: aldeslesbani@pps.unsri.ac.id (A. Lesbani) out any further treatments. Heavy metal polluted water commonly comes from the industrial process like electroplating, battery manufacture, metal extraction and even household activities [1-3]. These heavy metals are released regularly in various quantities and eventually accumulated in the environment where they were discharged. Heavy metals accumulation more than their allowable threshold will cause numerous detrimental environmental problems due to their high capability to involve in the 
food chain. Consequently, the removal of heavy metals form wastewater is crucial in order to provide a have metal free water resource.

Extensive procedures and methods have been applied to remove heavy metals from wastewater. Some of them are coagulation, extraction, membrane filtration, ion exchange, and adsorption [4-8]. Among these established methods, adsorption is considered as one of the most effective method to remove heavy metals from wastewater due to its high removal efficiency, simple and fast process [9-11]. However, the key factor to the successful adsorption process depend on the performance of the used adsorbent. Currently, numerous adsorbent materials have been tested to remove heavy metal form wastewater like zeolite [12], clays [13], bentonite [14-16], kaolin[17], algae[18], also synthetic layered material (layered double hydroxides) [19-21]. Recently, layered double hydroxides (LDHs) have gained considerable attention to be used as adsorbent due to their versatile metal composition and simple synthesis process.

LDHs are layered compound, similar to clay and clays mineral, that exhibited positively charged sheets due to the partial isomorphic substitution of the divalent metal cation by the trivalent cation [22]. This material has unique characteristic such as high anion exchange, reactive interlayer space, swelling in water, and colloidal properties [23]. LDH is inorganic materials with the general formula of $\left.\left[\mathrm{M}^{2+}{ }_{1-\mathrm{x}} \mathrm{M}^{3+}{ }_{\mathrm{x}}(\mathrm{OH})\right]^{\mathrm{x}+}\left(\mathrm{A}^{\mathrm{n}}\right)_{\mathrm{x} / \mathrm{n}}\right] \cdot \mathrm{nH}_{2} \mathrm{O}$, where $\mathrm{M}$ is divalent and trivalent metal ions, and $\mathrm{A}^{\mathrm{n}}$ - is interlayer anions with valence $n$ [24]. Some interlayer anions that commonly settled in the interlayer spacing of $\mathrm{LDH}$ are nitrate $\left(\mathrm{NO}_{3}\right)^{-}$, chloride (Cl-), sulfate $\left(\mathrm{SO}_{4}{ }^{2-}\right)$, and carbonate $\left(\mathrm{CO}_{3}{ }^{2-}\right)$ [25]. The schematic structure of $\mathrm{LDH}$ is presented in Figure 1. One of the most interesting properties of $\mathrm{LDH}$ is its anion exchange capability that can be utilized to modify its original structure. By changing the original interlayer anion with the larger anion, its interlayer distance and gallery can be expanded, and the surface area can be increased. After that, LDH can be used as potential inorganic material for various application like adsorbent, catalyst, biomedical material, and others industrial application.

Numerous researches on the application of $\mathrm{LDH}$ as an adsorbent of heavy metals have been conducted intensively. FeMnMg LDH has been used as an efficient adsorbent to remove $\mathrm{Pb}$ (II) ions in water [19]. Removal of Co(II) was effectively conducted using $\mathrm{MgAl} \mathrm{LDH}$ as adsorbent [26]. While the intercalated $\mathrm{MgAl} \mathrm{LDH}$ also showed good adsorption properties for removal of heavy metal form wastewater [27]. Considering these reported works, it can be indicated that intercalated LDH is a powerful adsorbent to remove heavy metals form solution. Various anionic intercalant like polyoxometalate, were frequently utilized for anion exchange in order to increase the interlayer distance of LDH [28-31]. By intercalating such that anion into LDH structure, the adsorption of heavy metal will more effective than the pristine form $\mathrm{LDH}$.

In this research, we reported the intercalation of $\mathrm{Ca} / \mathrm{Al} \mathrm{LDH}$ with Keggin ion [a-SiW $\left.\mathrm{S}_{12} \mathrm{O}_{40}\right]^{4-}$, and its utilization as adsorbent for iron(II) from aqueous solution. Although the preparation of $\left[\alpha-\mathrm{SiW}_{12} \mathrm{O}_{40}\right]^{4-}$ intercalated $\mathrm{Ca} / \mathrm{Al} \mathrm{LDH}$ has been reported previously, to the best of our knowledge, no work have ever been reported on the application of this material as an adsorbent for iron(II) removal. Furthermore, in order to simplify the intercalation process, we slightly modified the established intercalation method. The adsorption experiments were conducted using batch system and several factors that influencing adsorption process were studied, including effect of $\mathrm{pH}$, contact time, concentration of iron(II) solution, and temperature.

\section{Materials and Method}

\subsection{Chemical and Equipment}

Chemicals were used after purchased without purification from Merck and Sigma Aldrich, such as: calcium nitrate, iron(III) ni-

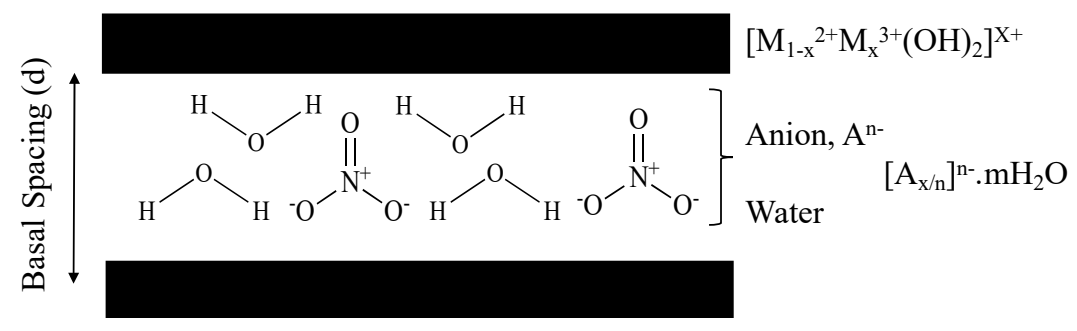

Figure 1. Structure of LDH 
trate, iron(II) nitrate, sodium hydroxide, aluminum nitrate, sodium tungsten, and sodium metasilicate. All the used chemicals were analytical grade reagents with $>99 \%$ purity level. The water that used in the experiment was supplied from Universitas Sriwijaya through ion exchange water purification system at $\mathrm{pH}$ 7.

X-Ray powder diffraction analysis was conducted using X-Ray powder diffraction Rigaku Miniflex-600, and the sample was scanned at scan speed $1^{\circ}$. min $^{-1}$. IR analysis was performed using FTIR Shimadzu Prestige-21 at wavenumber $400-4000 \mathrm{~cm}^{-1}$ using $\mathrm{KBr}$ pellet. Analysis of the residual iron(II) concentration was performed using UV spectrophotometer EMC61PC double beam spectrophotometer using 1,10-phenanthroline as complexing agent.

\subsection{Synthesis of $\mathrm{Ca} / \mathrm{Al} \mathrm{LDH}$}

Synthesis of $\mathrm{Ca} / \mathrm{AL} \mathrm{LDH}$ was conducted at pH 11 using co-precipitation method. The procedure was adopted from Granados-Reyes with modification [32]. Calcium nitrate and aluminum nitrate with molar ratio $2: 1 \quad\left(\mathrm{Ca}^{2+} / \mathrm{Al}^{3+}\right)$ was prepared by adding sodium hydroxide $2 \mathrm{M}$. The mixtures were stirred at $60{ }^{\circ} \mathrm{C}$ and $\mathrm{pH}$ was adjusted to 11 by slow addition of sodium hydroxide. $\mathrm{pH}$ of reaction mixture was adjusted until stable at $\mathrm{pH} 11$ during stirring process. After stable $\mathrm{pH}$, the mixtures were heated using autoclave at $120{ }^{\circ} \mathrm{C}$ for $2 \mathrm{~h}$. The mixtures were filtered at room temperature and washed with water and dried at $80{ }^{\circ} \mathrm{C}$ in a laboratory oven (overnight) to form white solid $\mathrm{Ca} / \mathrm{Al}$ $\mathrm{LDH}$. Ca/Al LDH was calcined at $800{ }^{\circ} \mathrm{C}$ using maffle furnace for 3 hours in order to know the stability of layer material. Characterization of $\mathrm{Ca} / \mathrm{Al} \mathrm{LDH}$ was performed using XRD and FTIR analyses.

\subsection{Synthesis of $\mathrm{K}_{4}\left[\alpha-\mathrm{SiW}_{12} \mathrm{O}_{40}\right] \times \mathrm{nH}_{2} \mathrm{O}$}

Ion [a- $\left.\mathrm{SiW}_{12} \mathrm{O}_{40}\right]^{4-}$ was synthesized as potassium salt $\mathrm{K}_{4}\left[\mathrm{a}-\mathrm{SiW}_{12} \mathrm{O}_{40}\right]$ in an aqueous medium. Sodium metasilicate (11 g) was dissolved into $100 \mathrm{~mL}$ of water (solution A). Sodium tungstate $(182 \mathrm{~g})$ was dissolved into $300 \mathrm{~mL}$ of boiling water (solution B). A solution of $4 \mathrm{M}$ $\mathrm{HCl}(165 \mathrm{~mL})$ was added drop by drop to solution A over 5 min with vigorous stirring in order to dissolve the local precipitate of tungstic acid. Then solution A was added quickly to solution $\mathrm{B}$ followed by adding $50 \mathrm{~mL}$ of $4 \mathrm{M} \mathrm{HCl}$. The $\mathrm{pH}$ was adjusted to 6 . The solution was kept at $373 \mathrm{~K}$ for 1 hour. A solution of $1 \mathrm{M}$ sodium tungstate $(50 \mathrm{~mL})$ and immediately there- after, $80 \mathrm{~mL}$ of $4 \mathrm{M} \mathrm{HCl}$ were added. The solution was filtered after cooling to room temperature. The potassium salt of $\mathrm{K}_{4}\left[\mathrm{a}-\mathrm{SiW}_{12} \mathrm{O}_{40}\right]$ was obtained by adjusting $\mathrm{pH}$ to around 2 with aqueous $1 \mathrm{M} \mathrm{KOH}$ and then solid $\mathrm{KCl}(50 \mathrm{~g})$ was added. A white precipitate of $\mathrm{K}_{4}[\mathrm{a}$ $\mathrm{SiW}_{12} \mathrm{O}_{40}$ ] was obtained [33]. $\mathrm{K}_{4}\left[\mathrm{a}-\mathrm{SiW}_{12} \mathrm{O}_{40}\right.$ ] was characterized using FT-IR spectrophotometer.

\subsection{Intercalation of $\mathrm{Ca} / \mathrm{Al} \mathrm{LDH}$ with $\left[\alpha-\mathrm{SiW}_{12} \mathrm{O}_{40}\right]^{4-}$}

$\mathrm{Ca} / \mathrm{Al} \mathrm{LDH}$ was intercalated using [a$\left.\mathrm{SiW}_{12} \mathrm{O}_{40}\right]^{4-}$ ion by ion exchange method. Potassium salt of $\mathrm{K}_{4}\left[\mathrm{a}-\mathrm{SiW}_{12} \mathrm{O}_{40}\right]$ was dissolved with water with a small quantity (solution $\mathrm{A}$ ). $\mathrm{Ca} / \mathrm{Al}$ $\mathrm{LDH}$ was mixed with a solution of sodium hydroxide (mixture B). Solution A was added into mixture $\mathrm{B}$ with gentle stirring under nitrogen condition. The white suspension was formed, and the reaction was performed for 24 hours. The white suspension was vacuum and wash with water. White material was kept at $110{ }^{\circ} \mathrm{C}$ for 48 hours. Characterization was performed using X-Ray powder analysis and identification using FTIR spectroscopy.

\subsection{Stability of $\mathrm{Ca} / \mathrm{Al} \mathrm{LDH}$ under various $\mathrm{pH}$}

The synthesized $\mathrm{Ca} / \mathrm{Al} \mathrm{LDH}$ and $\left[\alpha-\mathrm{SiW}_{12} \mathrm{O}_{40}\right]^{4-}$ intercalated $\mathrm{Ca} / \mathrm{Al} \mathrm{LDH}$ was contacted with iron(II) solution (50 mg. $\left.\mathrm{L}^{-1}\right)$ under vigorous stirring. The mixture was continuously stirred while the $\mathrm{pH}$ was adjusted at $\mathrm{pH} 1$ 10 by addition of sodium hydroxide or hydrochloric acid solution. Each of adsorbentsiron(II) mixture with different $\mathrm{pH}$ condition was analyzed using UV-Visible spectrophotometer and the spectra were recorded at wavelength of $300-700 \mathrm{~nm}$.

\subsection{Adsorption Experiment}

Adsorption of iron(II) was conducted using $\mathrm{Ca} / \mathrm{Al} \mathrm{LDH}$ as control and intercalated $\mathrm{Ca} / \mathrm{Al}$ $\mathrm{LDH}$. The adsorption process was studied through adsorption time, concentration of iron(II), and temperature. Variation of adsorption time was adjusted at 10,20,30,40,50,60, and $90 \mathrm{~min}$. Effect of initial concentration of iron(II) was varied in concentration $2,3,5,7,8$, 10, and $15 \mathrm{mg} . \mathrm{L}^{-1}$. Effect of temperature was studied at 30, 40, 50, 60, and $70{ }^{\circ} \mathrm{C}$. Filtrate of solution after adsorption was added with 1,10 phenanthroline to form $\mathrm{Fe}(\mathrm{II})-1,10$ phenanthroline complex then further analyzed using $\mathrm{UV}$ at $\lambda$ of $510 \mathrm{~nm}$. 


\section{Results and Discussion}

Ca/Al LDH was characterized by X-Ray powder analysis as shown in Figure 2a. Intensive diffraction was found at 20-50 deg, and small diffraction at $20^{\circ}-30^{\circ}$ indicated the crystalline phase of $\mathrm{Ca} / \mathrm{Al} \mathrm{LDH}$ due to the presence of anions such as nitrate and carbonate. Nitrate and carbonate anions were found in $\mathrm{Ca} / \mathrm{Al}$ LDH since the nitrate and carbonate metal salts were used as precursor in the synthesis process. These anions were located on the interlayer space of $\mathrm{Ca} / \mathrm{Al} \mathrm{LDH}$. The diffraction pattern of $\mathrm{Ca} / \mathrm{Al} \mathrm{LDH}$ after calcined at $800{ }^{\circ} \mathrm{C}$ was presented in Figure 1b. Diffraction at $20^{\circ}$ $50^{\circ}$ was sharply increased due to the release of water. In this step, mayenite at $53^{\circ}(640)$, and $56^{\circ}(642)$, and oxides phases were also detected. $\mathrm{Ca} / \mathrm{Al} \mathrm{LDH}$ was detected as layer material as mayenite which has composition $\mathrm{Ca}_{12} \mathrm{Al}_{14} \mathrm{O}_{33}$. Other phases were detected as Katoite at $17.3^{\circ}$ (211), $20.11^{\circ}(220), 28.5^{\circ}(321), 31.9^{\circ}$ (400), $36.58^{\circ}(420), 39.3^{\circ}(431), 44.6^{\circ}(521), 52.8^{\circ}$

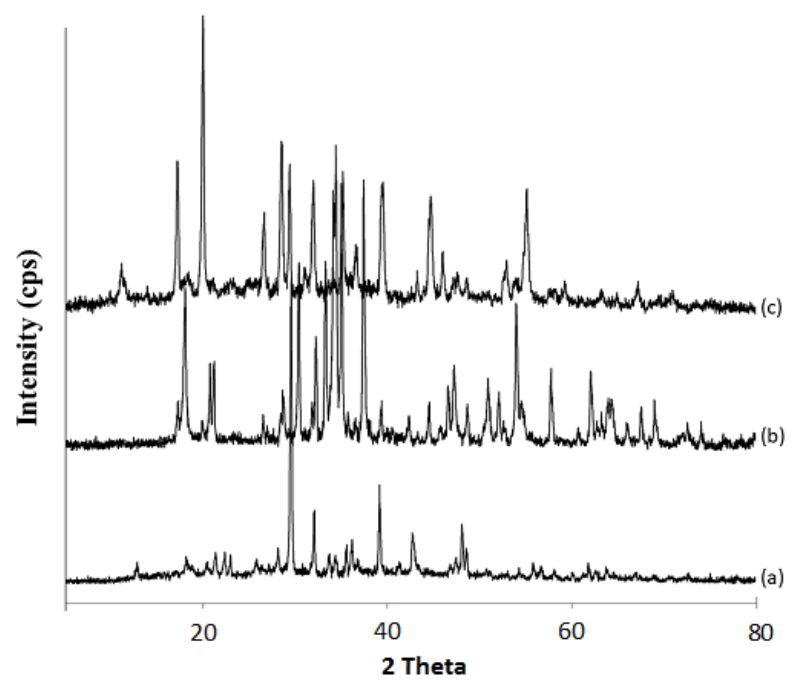

Figure 2. XRD powder pattern of $\mathrm{Ca} / \mathrm{Al} \mathrm{LDH}$ (a), calcination of $\mathrm{Ca} / \mathrm{Al} \mathrm{LDH}$ at $800{ }^{\circ} \mathrm{C}(\mathrm{b})$, and intercalated $\mathrm{Ca} / \mathrm{Al} \quad \mathrm{LDH} \quad$ with $\mathrm{K}_{4}\left[\alpha-\mathrm{SiW}_{12} \mathrm{O}_{40}\right] \times \mathrm{nH}_{2} \mathrm{O}(\mathrm{c})$
(611), $55.0^{\circ}(640)$, and $57.74^{\circ}(642)$ [32]. The interlayer distance of $\mathrm{Ca} / \mathrm{Al} \mathrm{LDH}$ was $4.25 \AA$. Figure 1c showed intercalated $\mathrm{Ca} / \mathrm{Al} \mathrm{LDH}$ with [a-SiW $\left.{ }_{12} \mathrm{O}_{40}\right]^{4-}$ ion. Diffraction at $20^{\circ}$ was sharper than before intercalation due to insertion of Kegin ion onto interlayer distance of $\mathrm{Ca} / \mathrm{Al}$ $\mathrm{LDH}$. The interlayer distance was found about $4.41 \AA$ A. Slightly changes of interlayer distance after intercalation process was probably due to the diagonal position of Keggin ion toward interlayer. Figure 3 showed that the possibility of Keggin ion onto interlayer $\mathrm{Ca} / \mathrm{Al} \mathrm{LDH}$ with Keggin ion intercalated in diagonal position of interlayer [24]. If position of intercalated Keggin ion with vertical orientation will results interlayer distance with largely value more than $3 \AA$ A. In this experiment we found that interlayer distance increases up to $0.16 \AA$.

FTIR spectrum of Ca/Al LDH was shown in Figure 4a. Sharp vibration at wavenumber $1380 \mathrm{~cm}^{-1}$ is assigned as nitrate ion on $\mathrm{Ca} / \mathrm{Al}$ $\mathrm{LDH}$. The existence of water is shown in vibration at $3410 \mathrm{~cm}^{-1}$ with the deep vibration of

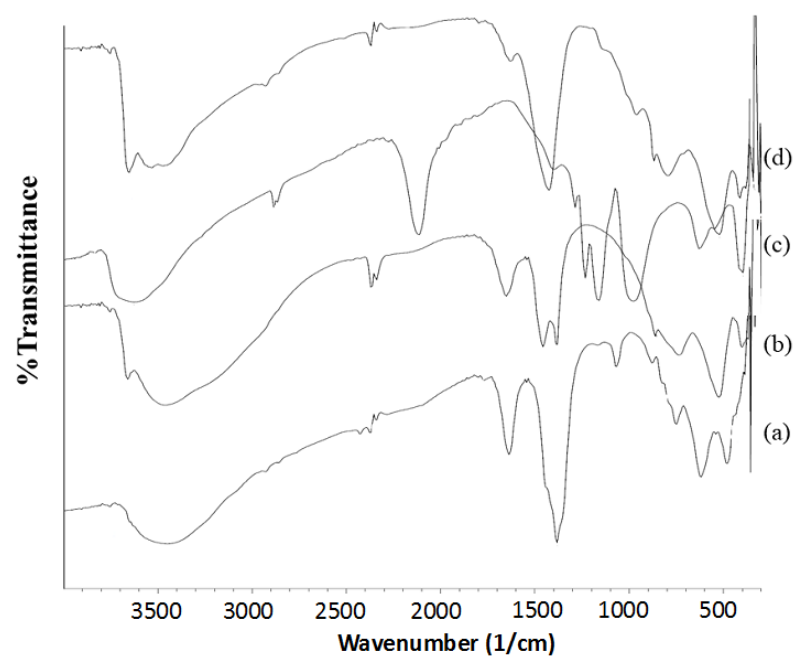

Figure 4. FTIR spectrum of $\mathrm{Ca} / \mathrm{Al} \mathrm{LDH}$ (a), calcination of $\mathrm{Ca} / \mathrm{Al} \mathrm{LDH}$ at $800{ }^{\circ} \mathrm{C}$ (b), polyoxometalate $\mathrm{K}_{4}\left[\alpha-\mathrm{SiW}_{12} \mathrm{O}_{40}\right] \times \mathrm{nH}_{2} \mathrm{O}$ (c), and intercalated $\mathrm{Ca} / \mathrm{Al} \mathrm{LDH}$ with $\mathrm{K}_{4}\left[\alpha-\mathrm{SiW}_{12} \mathrm{O}_{40}\right] \times \mathrm{nH}_{2} \mathrm{O}$ (d)

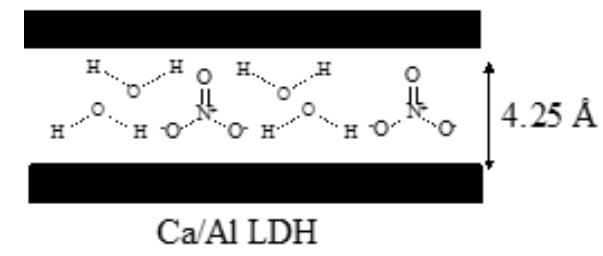

Figure 3. Illustration of intercalation $\mathrm{Ca} / \mathrm{Al} \mathrm{LDH}$ with $\left[\mathrm{a}-\mathrm{SiW}_{12} \mathrm{O}_{40}\right]^{4-}$ 
$\mathrm{OH}$. The vibration of nitrate was split into two bands due to the stability of nitrate at high temperature as shown in Figure 4b. Figure 4c shows the unique vibration of Keggin type polyoxometalate of $\mathrm{K}_{4}\left[\mathrm{a}-\mathrm{SiW}_{12} \mathrm{O}_{40}\right] \times \mathrm{nH}_{2} \mathrm{O}$ [34]. The unique vibration of $\mathrm{K}_{4}\left[\mathrm{a}-\mathrm{SiW}_{12} \mathrm{O}_{40}\right] \times \mathrm{nH}_{2} \mathrm{O}$ appeared at $926 \mathrm{~cm}^{-1}$ (n Si-O), $980 \mathrm{~cm}^{-1}(\mathrm{n} \mathrm{W}=\mathrm{O})$, $881 \mathrm{~cm}^{-1}(\mathrm{n} \mathrm{W}-\mathrm{Oc}-\mathrm{W})$, and $780 \mathrm{~cm}^{-1}$ (n W-Oe-W) [35]. Intercalation of $\mathrm{Ca} / \mathrm{Al} \mathrm{LDH}$ with Keggin ion resulted in spectra in Figure 4d. Intercalation with the large anion to $\mathrm{Ca} / \mathrm{Al} \mathrm{LDH}$ will affect to vibration of nitrate at $1380 \mathrm{~cm}^{-1}$. Thus, vibration at $1380 \mathrm{~cm}^{-1}$ after intercalation was broad and sharp.

The stability of $\mathrm{Ca} / \mathrm{Al} \mathrm{LDH}$ and intercalated $\mathrm{Ca} / \mathrm{Al} \mathrm{LDH}$ toward $\mathrm{pH}$ of iron(II) was determined using UV-Vis as shown in Figure 5. Figure 5a showed that $\mathrm{Ca} / \mathrm{Al} \mathrm{LDH}$ has the highest absorbance at $\mathrm{pH} 1$. On the other hand, intercalated Ca/Al with Keggin ion has the highest absorbance at $\mathrm{pH} 2$. However, all $\mathrm{pH}$ was an acidic condition. These phenomena can be explained because iron(II) was protonated in acid condition and form hydroxides in basic condition. These results were used for adsorption process of iron(II) using both $\mathrm{LDH}$ as adsorbents.

Adsorption of iron(II) firstly investigated by adsorption time and the data are presented in Figure 6. Adsorption of iron(II) was slowly at the initial time and increase sharply started at the first 30 minutes. Adsorption of iron(II) on $\mathrm{Ca} / \mathrm{Al} \mathrm{LDH}$ was relatively stable after 60 minutes. On the other hand, adsorption of iron(II) on intercalated LDH was continuously increased. In this case, intercalated $\mathrm{Ca} / \mathrm{Al} \mathrm{LDH}$ has kinetically more active than Ca/Al LDH without intercalation. These phenomena are

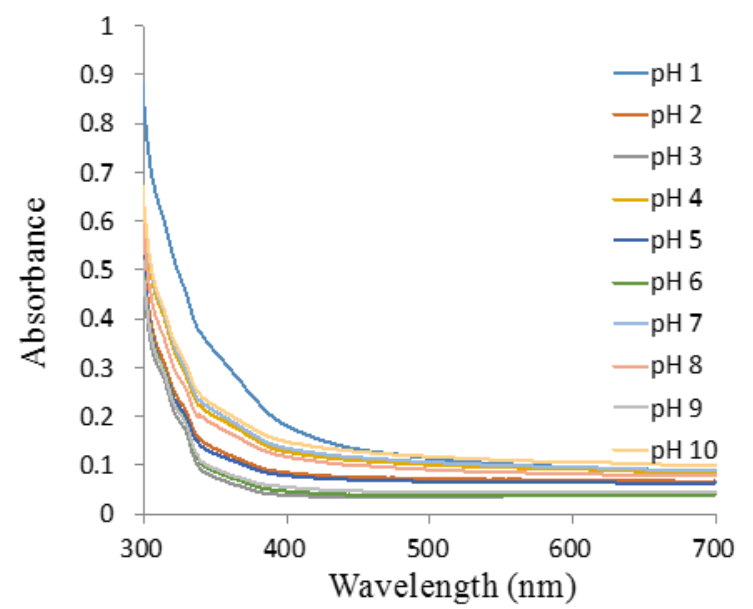

(a) probably due to opening layer volume of intercalated $\mathrm{Ca} / \mathrm{Al} \mathrm{LDH}$.

The data in Figure 6 was used to calculate the adsorption rate constant using LangmuirHinshelwood equation [36]. Adsorption rate constant for $\mathrm{Ca} / \mathrm{Al} \mathrm{LDH}$ and intercalated $\mathrm{Ca} / \mathrm{Al}$ $\mathrm{LDH}$ was $4.66 \mathrm{~min}^{-1}$ and $10.34 \mathrm{~min}^{-1}$, respectively. These results show intercalated $\mathrm{Ca} / \mathrm{Al}$ $\mathrm{LDH}$ has higher reactivity than $\mathrm{Ca} / \mathrm{Al} \mathrm{LDH}$ before intercalation to adsorp iron(II) from aqueous solution.

Adsorption of iron(II) on $\mathrm{Ca} / \mathrm{Al} \mathrm{LDH}$ and intercalated $\mathrm{Ca} / \mathrm{Al} \mathrm{LDH}$ was continued by the effect of concentration of iron(II) and temperature as shown in Figure 7a-b. Adsorption of iron(II) for both adsorbents show an increase by increasing temperature adsorption. Also, adsorption was increased by increasing concentration of iron(II). These results are generally occurred for adsorption of both for gas and liquid adsorbate in which adsorption capacity increase by increasing temperature. On the other hand, for both $\mathrm{Ca} / \mathrm{Al} \mathrm{LDH}$ and intercalated $\mathrm{Ca} / \mathrm{Al} \mathrm{LDH}$ have higher adsorption capacity at $40{ }^{\circ} \mathrm{C}$ than 60 and $70{ }^{\circ} \mathrm{C}$ at concentration of

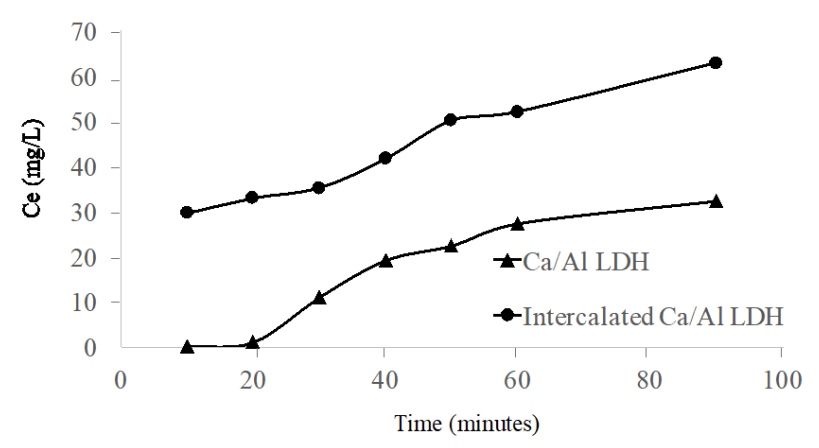

Figure 6. Effect of adsorption time of iron(II)

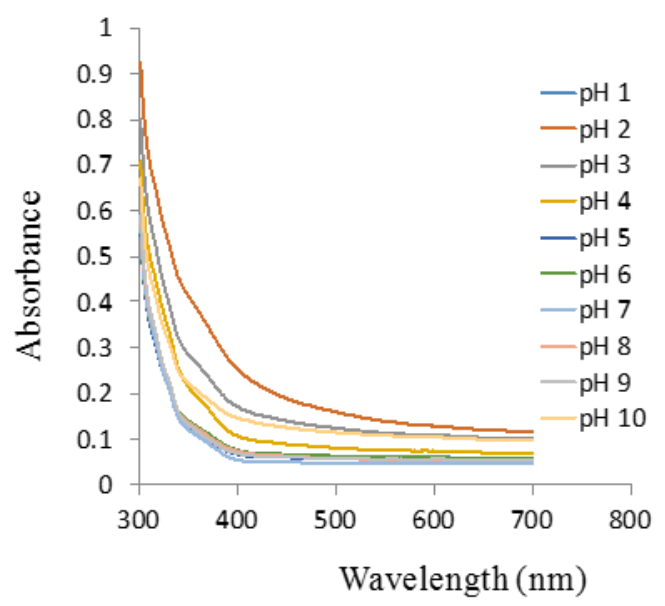

(b)

Figure 5. Stability of $\mathrm{Ca} / \mathrm{Al} \mathrm{LDH}$ (a) and intercalated $\mathrm{Ca} / \mathrm{Al}$ (b) under various $\mathrm{pH}$ 


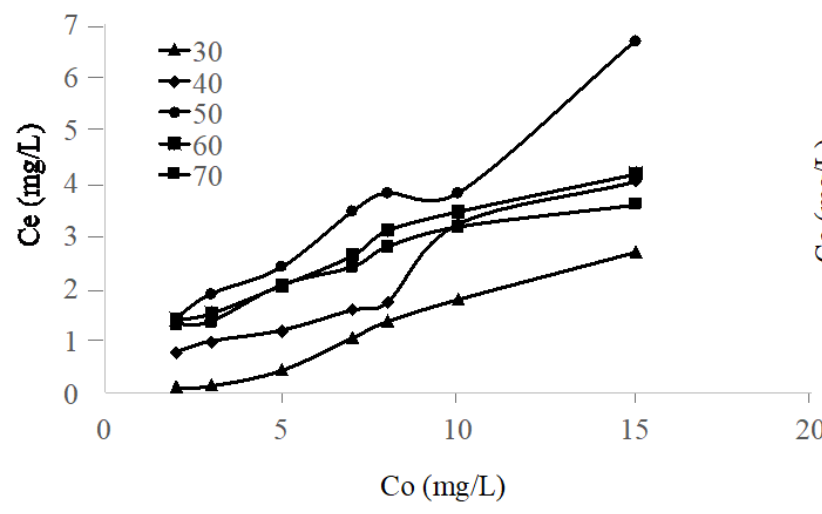

(a)

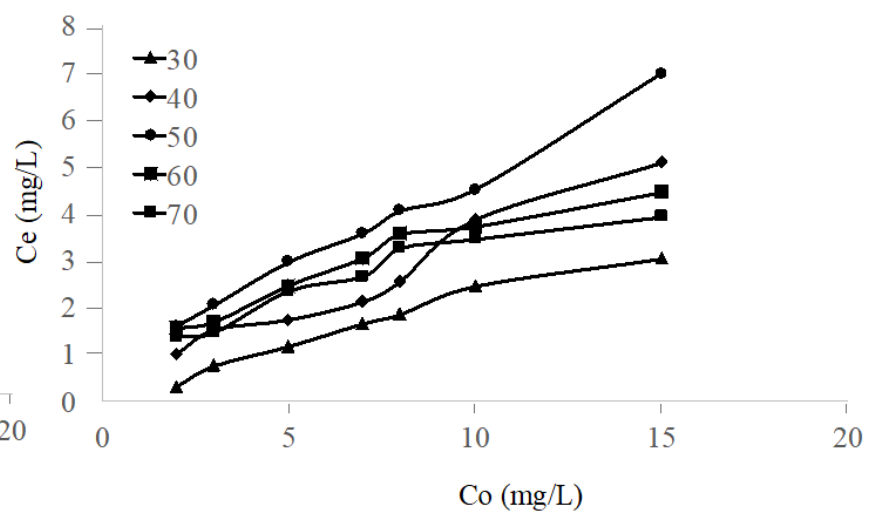

(b)

Figure 7. Effect of initial concentration of iron(II) and temperatures of adsorption iron(II) on Ca/Al $\mathrm{LDH}(\mathrm{a})$ and intercalated $\mathrm{Ca} / \mathrm{Al}(\mathrm{b})$

iron (II) $10 \mathrm{mg} . \mathrm{L}^{-1}$. The anomalies were also found at temperature $50{ }^{\circ} \mathrm{C}$ for both $\mathrm{Ca} / \mathrm{Al} \mathrm{LDH}$ and intercalated $\mathrm{Ca} / \mathrm{Al} \mathrm{LDH}$ where adsorption capacity was slightly increased. This finding probably was affected by the enough activation energy of iron(II) adsorption at that temperature. All data in Figure 7 were calculated using the Langmuir equation to obtain the adsorption capacity.

Adsorption capacity for $\mathrm{LDH}$ was shown in Table 1. As previously mentioned, that stability of iron(II) toward $\mathrm{LDH}$ at a higher temperature then adsorption capacity was decreased at 60$70{ }^{\circ} \mathrm{C}$ for both $\mathrm{Ca} / \mathrm{Al} \mathrm{LDH}$ and intercalated $\mathrm{Ca} / \mathrm{Al} \mathrm{LDH}$ due to the maximum activation energy was achieved. The results in Figure 7 and data in Table 1 also shows intercalated $\mathrm{Ca} / \mathrm{Al}$ $\mathrm{LDH}$ has higher adsorption capacity than $\mathrm{Ca} / \mathrm{Al}$ $\mathrm{LDH}$ at all temperatures. Thus, intercalated $\mathrm{Ca} / \mathrm{Al} \mathrm{LDH}$ gave substantial effect toward increasing adsorption iron(II) from aqueous solution.

Table 1. Adsorption capacity of LDH

\begin{tabular}{lcc}
\hline Adsorbent & $\begin{array}{c}\text { Temperature } \\
\left({ }^{\circ} \mathrm{C}\right)\end{array}$ & $\begin{array}{c}\text { Adsorption } \\
\text { Capacity } \\
\left.\times 10^{-3}\left(\mathrm{mg}^{-1}\right)^{-1}\right)\end{array}$ \\
\hline $\mathrm{Ca} / \mathrm{Al} \mathrm{LDH}$ & 30 & 1.78 \\
& 40 & 7.04 \\
& 50 & 11.16 \\
& 60 & 6.03 \\
& 70 & 4.97 \\
\hline Intercalated & 30 & 8.76 \\
Ca/Al LDH & 40 & 9.70 \\
& 50 & 11.93 \\
& 60 & 6.49 \\
& 70 & 5.69 \\
\hline
\end{tabular}

\section{Conclusion}

$\mathrm{Ca} / \mathrm{Al} \mathrm{LDH}$ was successfully intercalated using Keggin ion $\left[\mathrm{a}-\mathrm{SiW}_{12} \mathrm{O}_{40}\right]^{4-}$. X-ray diffraction result indicated that the Keggin ion was diagonally intercalated onto $\mathrm{Ca} / \mathrm{Al} \mathrm{LDH}$ interlayer space since there is a change on the diffraction at $20^{\circ}$ after intercalation. Furthermore, FT-IR spectra of the intercalated $\mathrm{Ca} / \mathrm{Al} \mathrm{LDH}$ also exhibited a vibration peak at $1380 \mathrm{~cm}^{-1}$ which indicated that the Keggin ion was inserted onto interlayer space of $\mathrm{Ca} / \mathrm{Al} \mathrm{LDH}$. The result of iron(II) adsorption onto pristine and intercalated $\mathrm{Ca} / \mathrm{Al} \mathrm{LDH}$ showed that intercalated $\mathrm{Ca} / \mathrm{Al}$ $\mathrm{LDH}$ has higher adsorption reactivity than its pristine form. In accordance with that results, intercalated $\mathrm{Ca} / \mathrm{Al} \mathrm{LDH}$ exhibited higher adsorption capacity toward iron(II) than the original Ca/Al LDH.

\section{Acknowledgement}

We thank Universitas Sriwijaya through "Hibah Profesi" 2017/2018 contract no. 987/UN9.3.1/PP/2017 for financial support of this research.

\section{References}

[1] Chen, S., Wu, D. (2018). Adapting ecological risk valuation for natural resource damage assessment in water pollution. Environmental Research, 164: 85-92. doi: 10.1016/j.envres.2018.01.005

[2] Wang, Q., Yang, Z. (2016). Industrial water pollution, water environment treatment, and health risks in China. Environmental Pollution, $218: \quad 358-365$. d o i : 10.1016/j.envpol.2016.07.011 
[3] Earnhart, D. (2013). Water Pollution from Industrial Sources. In J.F.B.T.-E. of E. Shogren Natural Resource, and Environmental Economics (Ed.), (pp. 114-120). Waltham: Elsevier. doi:10.1016/B978-0-12-375067-9.00091-7

[4] Noor, N.M., Othman, R., Mubarak, N.M., Abdullah, E.C. (2017). Agricultural biomassderived magnetic adsorbents: Preparation and application for heavy metals removal. Journal of the Taiwan Institute of Chemical Engineers, 78: 168-177. doi: 10.1016/j.jtice.2017.05.023

[5] Bhunia, B., Prasad Uday, U.S., Oinam, G., Mondal, A., Bandyopadhyay, T.K., Tiwari, O.N. (2018). Characterization, genetic regulation and production of cyanobacterial exopolysaccharides and its applicability for heavy metal removal. Carbohydrate Polymers, 179: 228-243.doi:10.1016/ j.carbpol.2017.09.091

[6] Tran, T.-K., Chiu, K.-F., Lin, C.-Y., Leu, H.-J. (2017). Electrochemical treatment of wastewater: Selectivity of the heavy metals removal process. International Journal of Hydrogen Energy, 42(45): 27741-27748. doi:10.1016/j.ijhydene.2017.05.156

[7] Hermawan, A.A., Chang, J.W., Pasbakhsh, P., Hart, F., Talei, A. (2018). Halloysite nanotubes as a fine grained material for heavy metal ions removal in tropical biofiltration systems. Applied Clay Science, 160: 106-115. doi:10.1016/j.clay.2017.12.051

[8] Taher, T., Saputri, L.I., Antini, R., Dian, A.R., Mohadi, R., Lesbani, A. (2018). An insight into the adsorption behavior of malachite green on DABCO (1,4-diazabicyclo [2.2.2] octane) modified bentonite. In AIP Conference Proceedings (Vol. 2026, p. 20010).

[9] Castro, L., Blázquez, M.L., González, F., Muñoz, J.A., Ballester, A. (2018). Heavy metal adsorption using biogenic iron compounds. Hydrometallurgy, 179: 44-51. doi:10.1016/j.hydromet.2018.05.029

[10] Sherlala, A.I.A., Raman, A.A.A., Bello, M.M., Asghar, A. (2018). A review of the applications of organo-functionalized magnetic graphene oxide nanocomposites for heavy metal adsorption. Chemosphere, 193: 1004-1017. doi:10.1016/j.chemosphere.2017.11.093

[11] Panda, L., Rath, S.S., Rao, D.S., Nayak, B.B., Das, B., Misra, P.K. (2018). Thorough understanding of the kinetics and mechanism of heavy metal adsorption onto a pyrophyllite mine waste based geopolymer. Journal of Molecular Liquids, 263: 428-441. doi:10.1016/j.molliq.2018.05.016

[12] Qiu, Q., Jiang, X., Lv, G., Chen, Z., Lu, S., Ni, M., Deng, X. (2018). Adsorption of heavy metal ions using zeolite materials of municipal solid waste incineration fly ash modified by microwave-assisted hydrothermal treatment. Powder Technology, 335: 156-163. doi:10.1016/j.powtec.2018.05.003

[13] Uddin, M.K. (2017). A review on the adsorption of heavy metals by clay minerals, with special focus on the past decade. Chemical Engineering Journal, 308: 438-462. doi:10.1016/j.cej.2016.09.029

[14] Tohdee, K., Kaewsichan, L., Asadullah, A. (2018). Enhancement of adsorption efficiency of heavy metal $\mathrm{Cu}$ (II) and $\mathrm{Zn}$ (II) onto cationic surfactant modified bentonite. Journal of Environmental Chemical Engineering, 6(2): 2821-2828. doi:10.1016/j.jece.2018.04.030

[15] Taher, T., Mohadi, R., Lesbani, A. (2018). Effect of $\mathrm{Ti}^{4+} /$ clay ratio on the properties of titanium pillared bentonite and its application for $\mathrm{Cr}(\mathrm{VI})$ removal. Rasayan Journal of Chemistry, 11(3): 1244-1254. doi:10.31788/RJC.2018.1133065

[16] Anirudhan, T.S., Jalajamony, S., Sreekumari, S.S. (2012). Adsorption of heavy metal ions from aqueous solutions by amine and carboxylate functionalised bentonites. Applied Clay S c i e n ce , $\quad 65-66$ : $67-71$. doi:10.1016/j.clay.2012.06.005

[17] Adebowale, K.O., Unuabonah, I.E., OluOwolabi, B.I. (2005). Adsorption of some heavy metal ions on sulfate- and phosphatemodified kaolin. Applied Clay Science, 29(2): 145-148. doi:10.1016/j.clay.2004.10.003

[18] Mohadi, R., Hanafiah, Z., Hermansyah, H., Zulkifli, H. (2017). Adsorption of procion red and congo red dyes using microalgae Spirulina sp. Science and Technology Indonesia, 2(4): 102-104. doi:10.26554/sti.2017.2.4.102104

[19] Zhou, H., Jiang, Z., Wei, S. (2018). A new hydrotalcite-like absorbent FeMnMg-LDH and its adsorption capacity for $\mathrm{Pb}^{2+}$ ions in water. Applied Clay Science, 153: 29-37. doi:10.1016/j.clay.2017.11.033

[20] Wang, T., Li, C., Wang, C., Wang, H. (2018). Biochar/MnAl-LDH composites for $\mathrm{Cu}$ (II) removal from aqueous solution. Colloids and Surfaces A: Physicochemical and Engineering As pects, $538: \quad 443-450$. doi:10.1016/j.colsurfa.2017.11.034

[21] Said, M., Rahayu Palapa, N. (2017). Adsorption of congo red using $\mathrm{Mg} / \mathrm{Al}$ hydrotalcite. Science \& Technology Indonesia, 1(2): 17-21. doi:10.26554/sti.2017.2.1.17-21

[22] Taher, T., Rohendi, D., Mohadi, R., Lesbani, A. (2018). Thermal and Acid Activation (TAA) of bentonite as adsorbent for removal of methylene blue: A kinetics and thermodynamic study. Chiang Mai Journal of Science, 45(4): 1770-1781. 
[23] Mishra, G., Dash, B., Pandey, S. (2018). Layered double hydroxides: A brief review from fundamentals to application as evolving biomaterials. Applied Clay Science, 153(October 2017): 172-186. doi:10.1016/j.clay.2017.12.021

[24] Xu, M., Bi, B., Xu, B., Sun, Z., Xu, L. (2018). Polyoxometalate-intercalated ZnAlFe-layered double hydroxides for adsorbing removal and photocatalytic degradation of cationic dye. A p plied Clay Science. doi:10.1016/j.clay.2018.02.023

[25] Hasannia, S., Yadollahi, B. (2015). Zn-Al LDH nanostructures pillared by $\mathrm{Fe}$ substituted Keggin type polyoxometalate: Synthesis, characterization and catalytic effect in green oxidation of alcohols. Polyhedron. doi:10.1016/j.poly.2015.08.020

[26] Zhao, J., Huang, Q., Liu, M., Dai, Y., Chen, J., Huang, H., Wei, Y. (2017). Synthesis of functionalized MgAl-layered double hydroxides via modified mussel inspired chemistry and their application in organic dye adsorption. Journal of Colloid and Interface Science, 505: 168-177. doi:10.1016/j.jcis.2017.05.087

[27] Rahman, M. T., Kameda, T., Kumagai, S., Yoshioka, T. (2018). A novel method to delaminate nitrate-intercalated $\mathrm{MgAl}$ layered double hydroxides in water and application in heavy metals removal from waste water. Chemos phere, 203 : $\quad 281-290$. doi:10.1016/j.chemosphere.2018.03.166

[28] Chen, Y., Yao, Z., Miras, H.N., Song, Y.-F. (2015). Modular Polyoxometalate-Layered Double Hydroxide Composites as Efficient Oxidative Catalysts. Chemistry - A European Journal, 21(30): 10812-10820. doi:10.1002/chem.201501214

[29] Ma, J., Yang, M., Chen, Q., Zhang, S., Cheng, H., Wang, S., Chen, Z. (2017). Comparative study of Keggin-type polyoxometalate pillared layered double hydroxides via two synthetic routes: Characterization and catalytic behavior in green epoxidation of cyclohexene. Applied Clay Science, 150: 210-216. doi:10.1016/j.clay.2017.09.030
[30] Carriazo, D., Lima, S., Martín, C., Pillinger, M., Valente, A.A., Rives, V. (2007). Metatungstate and tungstoniobate-containing LDHs: Preparation, characterisation and activity in epoxidation of cyclooctene. Journal of Physics and Chemistry of Solids, 68(10): 1872-1880. doi:10.1016/j.jpcs.2007.05.012

[31] Omwoma, S., Chen, W., Tsunashima, R., Song, Y.F. (2014). Recent advances on polyoxometalates intercalated layered double hydroxides: From synthetic approaches to functional material applications. Coordination $C h e m i s t r y \quad R e v i e w s$. doi:10.1016/j.ccr.2013.08.039

[32] Granados-Reyes, J., Salagre, P., Cesteros, Y. (2017). Effect of the preparation conditions on the catalytic activity of calcined $\mathrm{Ca} / \mathrm{Al}$-layered double hydroxides for the synthesis of glycerol carbonate. Applied Catalysis A: General, 536: 9-17. doi:10.1016/j.apcata.2017.02.013

[33] Lesbani, A., Kawamoto, R., Uchida, S., Mizuno, N. (2008). Control of structures and sorption properties of ionic crystals of $\mathrm{A}_{2}\left[\mathrm{Cr}_{3} \mathrm{O}\left(\mathrm{OOCC}_{2} \mathrm{H}_{5}\right)_{6}\left(\mathrm{H}_{2} \mathrm{O}\right)_{3}\right]_{2}\left[\right.$ alpha-SiW $\left.{ }_{12} \mathrm{O}_{40}\right]$ $\left(\mathrm{A}=\mathrm{Na}, \mathrm{K}, \mathrm{Rb}, \mathrm{NH}_{4}, \mathrm{Cs}\right.$. Inorganic chemistry, 47(8): 3349-3357. doi:10.1021/ic702333w

[34] Lesbani, A., Hensen, H., Taher, T., Hidayati, N., Mohadi, R., Andreas, R. (2018). Intercalation of $\mathrm{Zn} / \mathrm{Al}$ layered double hydroxides with Keggin ion as adsorbent of cadmium (II). In AIP Conference Proceedings (Vol. 2026, p. 20011).

[35] Mahjoubi, F.Z., Khalidi, A., Abdennouri, M., Barka, N. (2017). Zn-Al layered double hydroxides intercalated with carbonate, nitrate, chloride and sulphate ions: Synthesis, characterisation and dye removal properties. Journal of Taibah University for Science, 11(1): 90-100. doi:10.1016/j.jtusci.2015.10.007

[36] Chang, C.H., Franses, E.I. (1992). Modified Langmuir-Hinselwood kinetics for dynamic adsorption of surfactants at the air/water interface. Colloids and Surfaces, 69(2): 189-201. doi:10.1016/0166-6622(92)80230-Y 